\title{
最近の歯学
}

\section{4. 硬組織薬理}

新規骨吸収抑制薬の開発, 構造生物学からのアプローチ

東京医科㐘科大学大学院 医歯学総合研究科 生体硬組織再生学講座 硬組織薬理学分野 青木和広, 大谷啓一

高齢化社会を迎える我が国において，骨粗鬆症患者は約 1,000 万人と推定され，その数は今後も増加することが予想 される。また，最近は骨粗䉘症患者は，顎骨の減少をも引き 起こしており，さらには歯周病に罹患しやすいとの報告もあ る。骨は日々造り替えられており, 骨吸収と骨形成のバラン スによって骨量が維持されているが, 顎骨の吸收においても, 全身的もしくは局所的な原因によりその骨改造のバランスが 崩れ, 骨量減少が進んでいく。この際, 冎吸仪の主役となる 細胞が破骨細胞であり, 現在この破骨細胞をターゲットとし た骨吸収抑制薬の開発がさまざまな形で進んでいる。

最近，破骨細胞の分化や骨吸収活性を制御するシステムが 明らかとなってきた。すなわち, 破骨細胞の前駆細胞上もし くは骨吸収能力を有した成熟破骨細胞上: に存在する受容体 (RANK) と，その受容体に結合するリガンド (RANKL), そしてRANK と競合的怙抗をするオトリ受容体 (OPG) が 次々にクローニングされた ${ }^{1 \sim 4)}$ 。これら新規に発見された分子 群は, TNF/TNF 受容体ファミリーに属するタンパク質で あった。このオトリ受容体であるOPG をマウスに過㮃発現 させると, 破骨細胞がほとんど出現せず大理石骨病の症状を 示すことから, OPG の骨吸収抑制薬としての可能性が期待さ れていた ${ }^{21}$ 。ところが，OPGの分子量が非常に大きいことか ら, 抗原抗体反応のような副作用を起こす可能性がきわめて 大きく，創薬には作用部位の特定を行うなど，まだまだ開発 が必要と考えられている。

そこで，われわれはTNF 受容体上のリガンド認識部位に 似せて合成されたわずか 9 つのアミノ酸が, TNF- $\alpha$ の TNF 受容体に対する作用を抑制することに着目した。この合成ぺ プチドは分子量が非常に小さくかつ TNF- $\alpha$ の競合的拮抗 薬として効果を示すが5)，興味深いことに新規にクローニン グされた受容体 RANKにもこの TNF受容体上のリガンド 認識部位に相当するアミノ酸配列が存在した(図 1 )。このこ とから，われわれはこの合成ぺプチドが受谷体 RANKとそ のリガンド RANKLとの作用を競合的に抑制できると考え た。実際，この仮説はいくつかの in vitroの系を用いて証明 され6), RANKL 刺激による破骨細胞形成促進ならびに骨吸 収活性立進の両者ともこの合成ぺプチドにより抑制されるこ とが明らかとなった（論文投稿中）。

この in vitro の実験結果は非常に重要な意味を持つと思わ れる。なぜなら, TNF 受容体上のリガンドとの接触部位に似 せて合成されたぺプチドが, RANK を介する作用をブロック するとなれば， RANK/RANKLの立体構造解析から得た情 報から合成ぺプチドあるいは化合物を設計し，破骨細胞の分
化と機能発現を抑制するという骨吸収抑制薬開発への新たな るアプローチを示すことになるからである。現在, この合成 ペプチドの骨吸収抑制効果をin vivoの実験系を用いて検討 中である。

\section{文献}

1) Anderson, D. M., et al. : A homolog of the TNF receptor and its ligand enhance $\mathrm{T}$-cell growth and dendritic-cell function. Nature 390:175-179, 1997.

2) Simonet, W. S., et al. : Osteoprotegerin : a novel secreted protein involved in the regulation of bone density. Cell $89: 309-319,1997$.

3) Lacey, D. L., et al. : Osteoprotegerin ligand is a cytokine that regulates osteoclasto differentiation and activation. Cell 93: 165-176, 1998.

4) Yasuda, H., et al. : Osteoclast differentiation factor is a ligand for osteoprotegerin/osteoclastogenesis-inhibitory factor and is identical to TRANCE/RANKL. Proc. Natl. Acad. Sci. USA 95: 3597-3602, 1998.

5) Takasaki, W., et al. : Structure-based design and characterization of exocyclic peptidomimetics that inhibit TNF $\alpha$ binding to its receptor. Nat. Biotechnol. 15:1266-1270, 1997.

6) Aoki, K., et al. : A peptide antagonist mimicking the TNF recognition site on the TNF receptor inhibits vitamine $\mathrm{D}_{3} / \mathrm{PGE}_{2}$ - and RANK Ligand-induced osteoclastogenesis in vitro. J. Bone Miner. Res. $214: 178$, 1999 .

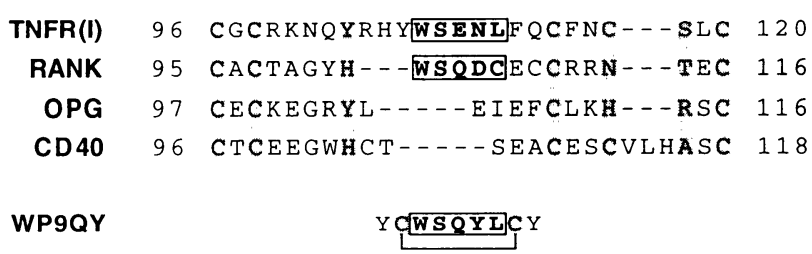

四 $1 \mathrm{TNF}$ 受容体ファミリーの細胞外ドメイン 3 における 相同配列と合成ぺプチドアンタゴニストWP 9 QY との 比較

$\mathrm{TNF}-\alpha$ との相互作用において最も重要な接触ポイン トは, TNF 受容体タイプ1（p 55）のドメイン 3 の最初 のルーブ構造にあり, BOX で示している。合成ぺプチド WP 9 QY はそのループに似せて合成された。p 55 上の そのループと相同性の高いアミノ酸残基も BOX で示し ているが，興味深いことに OPG や CD 40 にはその部位 に相当する残基がない。グレーの網かけバーは, ジスル フィド結合をするシステイン残基をはじめ，立体構造を 保つうえで重要な残基を示している。 